\title{
Evaluation of water quality and potential metal contamination in ecologically important Bhindawas bird sanctuary, India
}

\author{
Vandana $\operatorname{Shan}^{1}$-S. K. Singh ${ }^{1} \cdot$ A. K. Haritash ${ }^{1}$
}

Received: 22 November 2018 / Accepted: 26 November 2020 / Published online: 2 January 2021

(c) The Author(s) 2021

\begin{abstract}
Considering the environmental, agricultural, and ecological significance of Bhindawas wetland, the present study is the first comprehensive investigation to assess the water quality, determine the suitability of water for aquatic life in the wetland; and its suitability for irrigation in areas around the wetland. Twenty samples of water from Bhindawas wetland were analyzed and spatial variations of dissolved oxygen (DO), dissolved phosphate, nitrate, and biological oxygen demand $\left(\mathrm{BOD}_{5}\right)$ were observed. The concentration of DO was higher in areas with shallow depth and rich growth of submerged vegetation compared to deeper areas with no vegetation. Spatial variations of phosphate, nitrate, and heavy metals correlated with nesting zone of birds, runoff from agricultural fields, and wastewater from adjoining villages, respectively. Values of heavy metal pollution index (HPI), heavy metal evaluation index (HEI), and degree of contamination $\left(C_{\mathrm{d}}\right)$ in water confirmed high level of metal contamination of the medium. Based on the water quality index (WQI), the water was unsuitable for aquatic life and use in agricultural utilization. It can be concluded that water quality of Bhindawas wetland was adversely affected by heavy metals, which is a cause of concern since this wetland is a temporary resort of migratory birds. Immediate intervention is required to improve the water quality, especially scrutiny and inspection of the added wastewater from surrounding villages, and runoff from adjoining agricultural fields.
\end{abstract}

Keywords Bhindawas wetland · Water quality index (WQI) $\cdot$ Heavy metal pollution index (HPI) $\cdot$ Heavy metal evaluation index (HEI) · Principal component analysis (PCA)

\section{Introduction}

Water is an essential natural resource for every living organism on this planet. It is the most important factor for sustaining life. Fortunately, a huge amount of water is present on earth's surface, but safe drinking water is available as a limited fraction in rivers, lakes, streams, and wetlands. The wetlands are most diverse and highly productive aquatic ecosystems and are known as natural sponges of ecosystem as they absorb excess water, store nutrients/pollutants from agricultural runoff and drainage system. Wetlands act as a buffer between land and water ecosystem and maintain sediment and nutrient balance between them (Haritash et al. 2015). These act as habitats for birds and provide a platform

A. K. Haritash

akharitash@dce.ac.in

1 Department of Environmental Engineering, Delhi Technological University, Bawana Road, Shahbad Daulatpur, Delhi 110 042, India to native as well as migratory birds for resting, breeding, nesting, and rearing young ones. Water quality is a major factor in managing wetlands, which is affected by a number of parameters like seasons (Sharma et al. 2015), topography, type of soil, quantity of water, and vegetation present in it (Shelef et al. 2011). Increasing stress due to burgeoning population, intensified anthropogenic activities, urbanization, rapid industrialization, lack of proper legislation and lack of awareness contributed to rapid decline in water quality which ultimately will impose harmful effects on health of inhabitants (Senthil et al. 2012; Giri and Singh 2014). Many researchers assessed the water quality in order to draw out some information for management and conservation of wetlands. The water quality is an important tool, which classifies not only the type of water but also determines health status of the ecosystem. Whereas wetlands are important source of freshwater, these have also got in application in nutrient/pollutant removal and improving the water quality. Several studies have reported the role of wetlands in removal of suspended solids (Tanner et al. 1995), nutrients (Haritash 
et al. 2015, 2017), organic impurities (Fisher and Acreman 2004; Mohanty et al. 2014), pathogens (Rogers 1983), and even metals (Prasanna et al. 2012; Zhang et al. 2012). Realizing the ecological and environmental importance of wetlands, various conservation plans are going on in different states to conserve wetlands. India has 26 wetlands (Ramsar Sites) of international importance besides a number of other wetlands of national importance. Since the Northern states of India (J\&K, Himachal Pradesh, Rajasthan, and Haryana) lie enroute of migratory birds, the wetlands of these states have gained significant environmental importance as nesting and breeding grounds for migratory birds. Haryana is an important North Indian State with two important wetlands (Sultanpur and Bhindawas) which offer temporary habitat to migratory birds. Whereas Sultanpur wetland goes dry during summer season, Bhindawas is a man-made wetland with Jawahar Lal Nehru (JLN) Canal as source of water to maintain its water level. This man-made wetland is surrounded by the agricultural fields. During monsoon, water from the water-logged fields is pumped into the wetland which adds nutrients like phosphate and nitrate which and acts as a stimulus to eutrophication (Kaur and Singh 2012; Yadav et al. 2015; Haritash et al. 2015). Bhindawas and Sultanpur Bird Sanctuaries have also been identified under National wetland conservation programme as these water bodies have several species of animals, birds, and plants. Bhindawas wetland is also identified as an important wetland under International Wetland Conservation Programme of Ministry of Environment, Forests and Climate Change (MOEFCC), Govt. of India, because of its ecological importance. Over the past years, due to declining water level in the Bharatpur Bird Sanctuary in Rajasthan, the migratory water birds have started nesting in Bhindawas wetland during winter season (Haritash et al. 2015). Some studies have been carried out for physiochemical characterization of water and its eutrophication potential (Kumar and Dhankhar 2012; Saluja and Garg 2014), but studies dedicated to evaluation, overall quality and contamination due to heavy metals are very limited. Poor water quality has become an important issue, which ultimately affects ecosystem health and functioning and underpins biodiversity and is also responsible for major alterations in water use (Liang et al. 2016). In view of its ecological significance, it becomes imperative to monitor the water quality of Bhindawas wetland regularly. Since the water quality is an aggregated outcome of number of parameters, single numerical value called water quality index (WQI) has been suggested to represent it in simpler terms. It is evaluated by assigning weightage and rating to individual parameters against their standard prescribed values. Similarly, heavy metal evaluation index (HEI), heavy metal pollution index (HPI) and degree of contamination $\left(C_{\mathrm{d}}\right)$ can also be used to represent quality with respect to toxic heavy metals. Since the water of Bhindawas supports aquatic life and irrigation (in downstream stretch), and it receives the wastewater from adjoining villages, agricultural fields, and overflow from drain no. 8; addition of excess nutrients, organic impurities, and pollutants like heavy metals are significantly affecting the quality of water subsequently causing an effect of aquatic flora and fauna, agricultural crops and soil health. The present study was devised to carry a comprehensive assessment of water quality and metal toxicity in Bhindawas wetland.

\section{Materials and methods}

\section{Study area}

The present study was undertaken in Bhindawas wetland, which is located in Jhajjhar district of Haryana state. The wetland is located in a semiarid region with average temperature of $14{ }^{\circ} \mathrm{C}$ in winter and $47^{\circ} \mathrm{C}$ during summer with annual average rainfall of $800 \mathrm{~mm}$. The wetland was a protected forest and was declared as a Bird Sanctuary in the year 1986 by Ministry of Environment and Forests. Bhindawas wetland is located at $28^{\circ} 32^{\prime}$ North latitude and $76^{\circ} 32^{\prime}$ East longitude in Jhajjhar district of Haryana state. The wetland spreads over an area of 1074 Acres and gets water from monsoonal rains and excess spilling of JLN Canal. Almost $50 \%$ of the area of wetlands provide permanent water surface to plants like Eichhornia, Valliseneria, Salvinia etc. The wetland has sufficient number of trees like Acacia, Eucalyptus, Albizia etc. which provide surface for nesting within the wetland. It is regarded as Kaeoladeo National Park of Haryana (Gupta et al. 2011). This saucer shaper marshy area receives water from Jawahar Lal Nehru Canal during power failure and release extra water in Drain no.8. It is the largest wetland in all over Haryana with a periphery of $12 \mathrm{~km}$ and average water depth 6 feet. Due to water crisis in Kaeoladeo National Park (Bharatpur) last few years, Bhindawas wetland has gained increasing interest by migratory birds. It is being used by the migratory and resident birds of about 250 species. This sanctuary is situated in the centre of a number of villages namely Kanwah, Bilochpura, Nawada, Redhuwas, Shahjahanpur and Chadwana.

\section{Collection of samples and analysis}

For collection of samples of surface water, the wetland was divided into grids (20 in number) and one representative sample was collected from each grid (Fig. 1). The sampling was performed during the day time (11 a.m. to 2 p.m.) in during monsoon season (September, 2015). One sample each was collected JLN Canal (inlet of water) and drain no. 8 (outlet) to arrive at difference of different parameters within the wetland. Some of the parameters like pH, EC, 
Fig. 1 Location of sampling sites in Bhindawas wetland

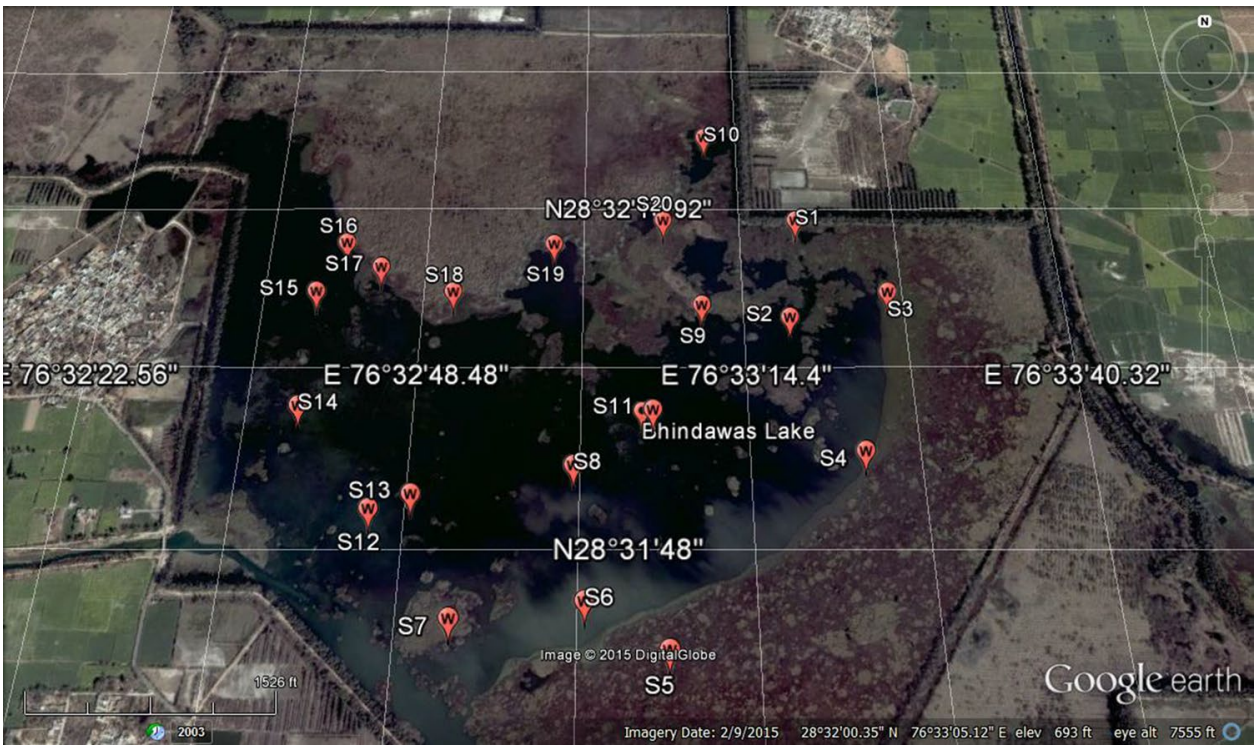

TDS, temperature and DO were analysed onsite using Orion (USA) make Star 320A + model. The samples were collected in pre-rinsed polypropylene bottles (1L), stored in an ice box and were transported to the laboratory immediately after collection. Total suspended solids (TSSs) were measured using gravimetric analysis; chlorides $\left(\mathrm{Cl}^{-}\right)$, total alkalinity (TA), and total hardness (TH) were determined by volumetric analysis; sulphate, nitrate, phosphate and dissolved ammonia were measured spectrophotometrically (Labtronics make LT-290 model); $\mathrm{Na}^{+}, \mathrm{K}^{+}, \mathrm{Mg}^{2+}$ and $\mathrm{Ca}^{2+}$ were measured flame photometrically (Systronics make $128 \mu$ model); and heavy metals $(\mathrm{Cu}, \mathrm{Fe}, \mathrm{Ni}, \mathrm{Pb}, \mathrm{Zn})$ were measured using atomic absorption spectrophotometer (Analytik Jena Nova 350). All the experiments were conducted in triplicates using AR Grade chemicals and type- 1 ultrapure water; and as per the standard methods prescribed by APHA (2005). The calculation of WQI for aquatic life and irrigation; and HPI and HEI for metal contamination was also undertaken. Statistical analysis of data was performed on SPSS version 20 to establish spatial similarities using cluster analysis; and major parameters affecting water quality by principal component analysis (PCA).

\section{Water quality index}

The water quality index (WQI) is a useful technique of rating that determines the collective influence of individual water quality parameter on the overall quality of water (AlMohammed and Mutasher 2013; Singh et al. 2015). WQI of Bhindawas Bird Sanctuary was calculated using the weighted arithmetic index method Brown et al (1972). For calculating the WQI in the present study, total 21 parameters (namely temperature, $\mathrm{pH}$, total dissolved solids, total suspended solids, dissolved oxygen, chemical oxygen demand, chlorides, nitrate nitrogen, ammonium nitrogen, phosphate, sulphate, $\mathrm{Ca}^{+2}, \mathrm{Mg}^{+2}, \mathrm{Na}^{+}, \mathrm{K}^{+}, \mathrm{Cu}^{+2}, \mathrm{Fe}^{+2}, \mathrm{Ni}^{+2}, \mathrm{~Pb}^{+2}$, $\mathrm{Zn}^{+2}$ ) were considered (Table 1 ). The quality rating (Qi) for each parameter (Qi) was calculated by using this expres$\mathrm{s}$ i o $\mathrm{n}$ : Quality rating $(\mathrm{Qi})=[(\mathrm{Cn}-\mathrm{Ci}) /(\mathrm{Cs}-\mathrm{Ci})] * 100$ where $\mathrm{Cn}$ : actual value of nth parameter; $\mathrm{Ci}$ : ideal value of this parameter; $\mathrm{Ci}=0$ (except $\mathrm{Ci}-7$ for $\mathrm{pH}$; and $\mathrm{Ci}-14.6 \mathrm{mg} / \mathrm{l}$ for DO); and Cs: recommended standard of corresponding parameter. Relative weight (Wi) was calculated by a value inversely proportional to the recommended standard ( $\mathrm{Si}$ ) of the corresponding parameter.

$\mathrm{Wi}=1 / \mathrm{Si}$

Overall WQI was calculated by using equation:WQI $=\left(\sum i=1-n \mathrm{QiWi}\right) /\left(\sum i=1-n \mathrm{Wi}\right)$ where Qi is the sub quality index of $i$ th parameter; $W$ is the unit weight of each parameter; and $n$ is the number of parameters.

The classification of water quality based on WQI was done as per the criteria given below (Chatterji and Raziuddin 2002).

\begin{tabular}{lll}
\hline WQI value & Rating of water quality & Grading \\
\hline $0-25$ & Excellent & A \\
$26-50$ & Good & B \\
$51-75$ & Poor & C \\
$76-100$ & Very poor & D \\
Above 100 & Unsuitable for drinking & E \\
\hline
\end{tabular}

\section{Calculation of metal contamination}

Indexing concept helps in determining the status of water quality with respect to selected parameters. To understand 
Table 1 Average concentration of physico-chemical characteristics of water samples collected from Bhindawas wetland

\begin{tabular}{|c|c|c|c|c|}
\hline \multirow[t]{2}{*}{ Parameter } & \multirow[t]{2}{*}{ Mean \pm SD } & \multirow{2}{*}{$\begin{array}{l}\text { Range (Min.- } \\
\text { Max.) }\end{array}$} & \multicolumn{2}{|c|}{ Prescribed standard (Si) } \\
\hline & & & Aquatic life $^{\mathrm{a}}$ & Irrigation $^{\mathrm{b}}$ \\
\hline $\mathrm{pH}$ & $8.0 \pm 0.62$ & $7.1-9.6$ & 8 & 8.5 \\
\hline Temp & $33.0 \pm 0.47$ & $32.2-33.9$ & 20 & - \\
\hline $\mathrm{EC}$ & $472.5 \pm 26.15$ & $403-508$ & - & 3000 \\
\hline TDS & $234.3 \pm 9.62$ & $203-250$ & 500 & 2000 \\
\hline TSS & $464.5 \pm 111.60$ & $290-684$ & +25 & - \\
\hline TA & $100 \pm 24$ & $0-117$ & 20 & - \\
\hline $\mathrm{TH}$ & $166.40 \pm 24.15$ & $108-224$ & - & - \\
\hline BOD & $5.16 \pm 1.55$ & $3.14-9.46$ & - & - \\
\hline DO & $8.1 \pm 2.08$ & $5.3-13.3$ & 5.5 & - \\
\hline COD & $23.2 \pm 0.45$ & $23-24$ & 7 & - \\
\hline DOC & $17.48 \pm 5.55$ & $8.68-38.76$ & - & \\
\hline $\mathrm{Cl}^{-}$ & $58.2 \pm 7.62$ & $52-88$ & 120 & 1063 \\
\hline $\mathrm{SO}_{4}{ }^{2-}$ & $85.3 \pm 50.99$ & $27-240$ & - & 960 \\
\hline $\mathrm{Ca}^{2+}$ & $18.8 \pm 1.06$ & $15-20$ & - & 400 \\
\hline $\mathrm{Mg}^{2+}$ & $17.3 \pm 6.03$ & $7-28$ & - & 60 \\
\hline $\mathrm{Na}^{+}$ & $31.3 \pm 1.30$ & $30-34$ & - & 919 \\
\hline $\mathrm{K}^{+}$ & $2.4 \pm 0.38$ & $1.1-3.0$ & - & 2 \\
\hline $\mathrm{NO}_{3}^{-} \mathrm{N}$ & $14.2 \pm 11.43$ & $0-44.1$ & 2.93 & 10 \\
\hline $\mathrm{NH}_{3}{ }^{+} \mathrm{N}$ & $0.5 \pm 0.26$ & $0.2-1.4$ & 1.37 & 5 \\
\hline TKN & $4.20 \pm 4.56$ & $1.4-22.4$ & & \\
\hline $\mathrm{PO}_{4}^{3-}$ & $4.9 \pm 2.98$ & $0.4 .2-10.6$ & - & 2 \\
\hline $\mathrm{Cu}^{2+}$ & $0.08 \pm 0.04$ & $0-0.11$ & 0.004 & 0.2 \\
\hline $\mathrm{Fe}^{2+}$ & $0.7 \pm 0.37$ & $0.42-1.90$ & 0.3 & 5 \\
\hline $\mathrm{Ni}^{2+}$ & $0.2 \pm 0.04$ & $0.17-0.32$ & 0.025 & 0.2 \\
\hline $\mathrm{Pb}^{2+}$ & $1 \pm 0.71$ & $0.21-3.5$ & 0.007 & 5 \\
\hline $\mathrm{Zn}^{2+}$ & $0.01 \pm 0.04$ & $0-0.16$ & 0.050 & 2 \\
\hline
\end{tabular}

*Except $\mathrm{pH}$, temperature $\left({ }^{\circ} \mathrm{C}\right)$, and $\mathrm{EC}(\mu$ siemens $/ \mathrm{cm})$ all parameters have units in $\mathrm{mg} / \mathrm{l}$

${ }^{\mathrm{a} C C M E-C a n a d i a n}$ Council of Ministers of the Environment; ${ }^{\mathrm{b}} \mathrm{FAO}-$ Food and Agriculture Organization

the contamination level of the lake with respect to heavy metal, two different quality indices were used to calculate the metal pollution of Bhindawas wetland.

\section{Heavy metal pollution index (HPI)}

HPI index helps in determining the water quality status of surface water with respect to various selected parameters. For calculating HPI, each chosen parameter is assigned a rating or weightage (Wi) which is an arbitrary value, lies between 0 and 1 and defined as inversely proportional to standard permissible values $(\mathrm{Si})$ for each selected parameter. HPI is calculated by using following equation (Mohan et al. 1996):

$$
\mathrm{HPI}=\left(\sum i=1-\mathrm{n} \mathrm{QiWi}\right) /\left(\sum i=1-\mathrm{nWi}\right)
$$

where Wi and Qi are the unit weight of $i$ th parameter and sub index, respectively; and $n$ is the number of parameters considered. The value of sub index (Qi) is calculated by using equation:

$\mathrm{Qi}=\sum i=1-n[(\mathrm{Ci}-\mathrm{Ii}) /(\mathrm{Si}-\mathrm{Ii})] * 100$

where $\mathrm{Ci}, \mathrm{Si}$, and $\mathrm{Ii}$ are the observed value of heavy metal, standard value of $i$ th parameter, and ideal values, respectively. And the (-) sign denotes the numerical difference between two values, ignoring the algebraic sign.

\section{Heavy metal evaluation index (HEI)}

In metal index, the relative contamination of different metals was calculated and a single representative number is identified which is calculated by dividing sum of all the concentrations of heavy metals by sum of maximum allowable concentrations of each heavy metal studied. If the concentration of a metal is higher as compared to its respective MAC value, it represents the worse quality of the water. MI value $>1$ is a threshold of warning (Bakan et al. 2010). The MI is calculated by using the following formula (Edet and Offiong 2002):

$\mathrm{HEI}=\sum i=1-n(\mathrm{Ci} / \mathrm{MACi})$

where $\mathrm{Ci}$ is the observed concentration of each element, and MAC is the maximum allowable concentration.

\section{Degree of contamination $\left(C_{d}\right)$}

Combined effect of various water quality parameters is summarized in a single index called contamination index (Backman et al. 1997) and is expressed as:

$\mathrm{Cd}=\sum i=1-n \mathrm{Cfi}$

whereCfi $=(\mathrm{Coi} / \mathrm{Cni})-1$. where Cfi, Coi, and Cni are contamination factor, observed value, and normative value, respectively. Here, normative value is taken same as MAC value.

\section{Results and discussion}

The physicochemical characteristics of collected samples of water revealed that almost all the cations, anions, and other organic pollutants were present to detectable levels (Table 1). Another important observation was the significant differences in levels of dissolved oxygen, phosphate, sulphate, nitrate, dissolved oxygen, and organic carbon in inlet and outlet, as well as spatially within the wetland. 


\section{General observations}

The average temperature of water within the wetland was $33{ }^{\circ} \mathrm{C}$ with negligible/insignificant spatial variations, but it was significantly higher than the temperature at inlet and outlet. The reason for the relatively low temperature of inlet and outlet may be ascribed to more depth and turbulence, respectively. This could be affirmed by relatively lower value of dissolved oxygen $(0.7 \mathrm{mg} / \mathrm{l})$ in inlet (owing to more depth); and higher value $(6.6 \mathrm{mg} / \mathrm{l})$ at outlet. Rest of the parameters like TDS, pH, TSS and chloride had minimum spatial variations with mean value of $243 \mathrm{mg} / \mathrm{l}$, $8.0,465 \mathrm{mg} / \mathrm{l}$ and $58 \mathrm{mg} / \mathrm{l}$ respectively. The levels of dissolved oxygen were observed to be higher at location S11 $(12.3 \mathrm{mg} / \mathrm{l})$ and $\mathrm{S} 15(13.3 \mathrm{mg} / \mathrm{l})$ which may be ascribed to lower depth at the locations, which favoured rich growth submerged vegetation particularly Hydrilla and Vallisneria at these locations. Higher rate of subsurface photosynthetic activity at such locations may raise levels of dissolved oxygen. Similar observations have been reported in other studies too (Haritash et al. 2015). Average concentration of organic impurities in terms of $\mathrm{BOD}_{5}$ and COD was $4 \mathrm{mg} / \mathrm{l}$ and $23 \mathrm{mg} / \mathrm{l}$, respectively. Major source of organic impurities in the wetland in autochthonous originating from death and decomposition of plant and animal biomass. Relatively high values of BOD at location S19 and S20 may be attributed to accumulation of dead plant biomass of Eichhornia, Salvinia etc. along the northern shallow region of wetland. The level of hardness and alkalinity, calcium, magnesium, sodium, and potassium were almost uniform throughout the wetland. Lower level of calcium at location S11 may be ascribed to its precipitation as $\mathrm{CaCO}_{3}$ at $\mathrm{pH}^{>}$9.0. It may also result in precipitation of phosphate subsequent upon its binding with calcium. Lower concentration of phosphate at S11 location $(0.42 \mathrm{mg} / \mathrm{l})$ is a confirmation of co-precipitation of $\mathrm{Ca}^{2+}$ and $\mathrm{PO}_{4}{ }^{3-}$. Similar relationship of phosphate was observed with $\mathrm{pH}$ at other locations too. Very high concentration at locations S10 (10.6 mg/l) and S18 (10.2 mg/l) is contributed by more bird droppings at these locations. These locations are near to the shore with sufficient number of trees serving as nesting grounds for the aquatic birds. Disposal of $\mathrm{PO}_{4}{ }^{3-}$ rich droppings at these locations resulted in higher concentration, and relatively low $\mathrm{pH}$ at these locations keeps the phosphate in water soluble state. Significant difference in concentration of phosphate in inlet $(1.1 \mathrm{mg} / \mathrm{l})$ and outlet $(7.8 \mathrm{mg} / \mathrm{l})$ indicates that phosphate has accumulated in the water body over the period of time and most of it circulates within the wetland ecosystem. The other non-quantified source of import of phosphate to the wetland is pumping of water from adjoining water-logged fields during monsoon and post monsoon. Similarly, the concentration of nitrate in inlet $(9 \mathrm{mg} / \mathrm{l})$ and outlet $(19.7 \mathrm{mg} / \mathrm{l})$ had significant difference, which may also be ascribed to import from pumped of water from agricultural fields. Spatial variations in level of nitrate were observed within the wetland with values varying from 3.8 to $44.1 \mathrm{mg} / \mathrm{l}$. Higher values at certain locations may be an outcome of higher oxidising potential and improved microbial activity. Dissolved ammonia, on the other hand, was very low in concentration with an average value of $0.5 \mathrm{mg} / \mathrm{l}$. Its concentration was high in inlet $(1.1 \mathrm{mg} / \mathrm{l})$ and less in the wetland owing to relatively stronger oxidising conditions in the wetland. Similarly, Total Kjeldahl's nitrogen $(\mathrm{TKN})$ was moderate in concentration with an average value of $3.4 \mathrm{mg} / \mathrm{l}$.

Apart from the general parameters, heavy metals $(\mathrm{Fe}, \mathrm{Zn}$, $\mathrm{Ni}, \mathrm{Cu}, \mathrm{Pb}$ ) were also reported in water of Bhindawas wetland. The average value of iron, zinc and nickel was found to be $0.7 \mathrm{mg} / \mathrm{l}, 0.01 \mathrm{mg} / \mathrm{l}$ and $0.2 \mathrm{mg} / \mathrm{l}$, respectively, which may be a cause of concern for the aquatic life present in the wetland since these metals are bio accumulative in nature. Similarly, high mean concentration of copper $(0.03 \mathrm{mg} / \mathrm{l})$ and lead $(0.96 \mathrm{mg} / \mathrm{l})$ that the metals are gradually accumulating in the wetland compared to the level in inlet confirms that these metals are gradually accumulating in the wetland (Table 2).

Exceedance of levels and its effect depends on degree and frequency of exceedance, chemical nature of the pollutant, its toxicity, and its interaction with other pollutants. Comparison of individual parameters against the prescribed standards will not provide sufficient information to arrive at aggregated quality. Water quality index is an aggregated numerical value which represents the quality of water based on values of given set of parameters. In the present study, evaluation of WQI has been done to determine the water quality for survival of aquatic life and use in irrigation. Based on the values of WQI for agriculture use, the water was classified as very poor or unsuitable for use upon comparison with standards prescribed by FAO (1994). The major parameters, which exceeded the prescribed standards, were nitrate, phosphate, and potassium at most of the location, which clearly indicates the input from NPK fertilisers being employed in fields. The water being pumped into the wetland from adjoining water-logged fields during monsoon is, therefore, the dominant source and reason for compromised quality of water. Based on WQI for survival of aquatic life, the water was found to be unsuitable upon comparison with standards prescribed by CCME (2007).

\section{Heavy metal pollution index (HPI)}

HPI is based on the weight (Wi) of the metals analysed in a study. The weight or rating varies between 0 and 1 and it indicates the relative significance of an individual metal and it is evaluated by inverse proportion of the standard/ normative value $(\mathrm{Si})$ of that metal. The normative value used for calculated HPI values for irrigation and aquatic use 
Table 2 Classification of water in Bhindawas wetland based on HPI, HEI, degree of contamination and WQI

\begin{tabular}{|c|c|c|c|c|c|c|c|c|}
\hline \multirow[t]{2}{*}{ Index } & \multicolumn{4}{|c|}{ Aquatic life } & \multicolumn{4}{|l|}{ Irrigation } \\
\hline & $\begin{array}{l}\text { Modified } \\
\text { category }\end{array}$ & $\begin{array}{l}\text { Degree of pol- } \\
\text { lution }\end{array}$ & $\begin{array}{l}\text { No. of samples } \\
(\%)\end{array}$ & $\begin{array}{l}\text { Mean (Range) } \\
\text { (Min.-Max.) }\end{array}$ & $\begin{array}{l}\text { Modified } \\
\text { category }\end{array}$ & $\begin{array}{l}\text { Degree of pol- } \\
\text { lution }\end{array}$ & $\begin{array}{l}\text { No. of samples } \\
(\%)\end{array}$ & $\begin{array}{l}\text { Mean (Range) } \\
\text { (Min.-Max.) }\end{array}$ \\
\hline \multirow[t]{3}{*}{ HPI } & $<50$ & Low & $13(65)$ & $48(25-161)$ & $<1$ & Low & $19(95)$ & $0.7(0.5-1.3)$ \\
\hline & $50-100$ & Medium & $06(30)$ & & $1-2$ & Medium & $1(5)$ & \\
\hline & $>100$ & High & $01(05)$ & & $>2$ & High & - & \\
\hline \multirow[t]{3}{*}{ HEI } & $<160$ & Low & $13(65)$ & $160(68-519)$ & $<2$ & Low & $17(85)$ & $1.7(1.1-2.2)$ \\
\hline & $160-320$ & Medium & $06(30)$ & & $2-4$ & Medium & $03(15)$ & \\
\hline & $>320$ & High & $01(05)$ & & $>4$ & High & - & \\
\hline \multirow[t]{3}{*}{$C_{\mathrm{d}}$} & $<150$ & Low & $13(65)$ & $152(63-514)$ & $<-3$ & Low & $17(85)$ & $\begin{array}{l}-3.3(-3.9 \text { to } \\
-2.8)\end{array}$ \\
\hline & $150-320$ & Medium & $06(30)$ & & $-3-0$ & Medium & & \\
\hline & $>320$ & High & $01(05)$ & & $>0.0$ & High & $03(15)$ & \\
\hline \multirow[t]{5}{*}{ WQI } & $0-25$ & Excellent & Nil & $194(101-384)$ & $0-25$ & Excellent & Nil & $143(53-257)$ \\
\hline & $25-50$ & Good & Nil & & $26-50$ & Good & Nil & \\
\hline & $51-75$ & Poor & Nil & & $51-75$ & Poor & $2(10)$ & \\
\hline & $76-100$ & Very Poor & Nil & & $76-100$ & V. Poor & $4(20)$ & \\
\hline & $>100$ & Unsuitable & $20(100)$ & & $>100$ & Unsuitable & $14(70)$ & \\
\hline
\end{tabular}

have been extracted from FAO (1994) and CCME (2007), respectively. In the present study, the degree of pollution was observed to be low for $65 \%$; medium for $35 \%$ and high for only $5 \%$ of samples for aquatic life. The observed values of HPI for aquatic life varied from 25 to 160 . Relatively higher values were observed at locations S12 to S18 adjoining Chadwana village in northeast region of the wetland. Higher levels of heavy metals in that particular region may be ascribed to pumping of domestic sewage from the adjoining village. This indicates that the water quality is questionable for aquatic life. It becomes a cause of concern since Bhindawas wetland is a temporary nesting ground for the migratory birds during the winter season. On the other hand, degree of pollution was low for use in irrigation. The values varied between 0.4 and 0.9 indicating that the heavy metals were within the safe limits for use in agriculture. Since the heavy metal uptake by plants is selective and restrictive, relatively smaller fractions are assimilated in the plant tissue. Therefore, the standard limits for use in irrigation are relaxed/higher which results in low values of HPI for agricultural use. The classification of degree of pollution for aquatic and agricultural use is given in Table 3.

\section{Heavy metal evaluation index (HEI)}

HEI is an indication of aggregated quality of water with respect to the analysed heavy metals. It is used for a clear understanding and validation of other pollution indices by synchronising the classification criteria of the other indices. Based on the values of HEI, $65 \%$ of the samples add low degree of pollution; $30 \%$ had medium; and $5 \%$ of the sample had the high degree of the pollution as observed in case of HPI. The only sample, which had maximum HEI value, was collected from S12 location adjoining Chaddwana village. Unlike HPI $85 \%$ of the samples add low degree of pollution and $15 \%$ add medium degree of pollution for use in irrigation. The locations S12 and S15 were observed to have relatively high metal concentration. The classification of water based on HEI is given in Table 3.

\section{Degree of contamination $\left(C_{d}\right)$}

The degree of contamination/contamination index $\left(C_{\mathrm{d}}\right)$ is another representation of the quality of water with respect to the heavy metal concentration. Based on the values of $C_{\mathrm{d}}$, $65 \%$ samples had low; $30 \%$ medium; and 5\% samples having high degree of pollution confirming to the classification as observed for HPI and HEI of water for aquatic life. Similarly, for use in irrigation, 85\% samples had low and 15\% had medium degree of pollution, which was in conformance with the classification observed for the HEI. The details of $C_{\mathrm{d}}$ are given in Table 3. Based on various indices (HPI, HEI, $C_{\mathrm{d}}$ ), for degree of pollution most of the locations were having good quality of water for irrigation and aquatic life with the only exception of region adjoining rural habitation in north east region of the wetland. For aquatic life, all three indices had similar classification for quality and validated each other. For agricultural quality, $C_{\mathrm{d}}$ and HEI had similar values and were $85 \%$ in conformance with HPI. 
Table 3 Principal component analysis for selected parameters of water in Bhindawas wetland

\begin{tabular}{|c|c|c|c|c|c|c|c|c|}
\hline \multirow[t]{2}{*}{ Variables } & \multicolumn{8}{|c|}{ Components } \\
\hline & 1 & 2 & 3 & 4 & 5 & 6 & 7 & 8 \\
\hline $\mathrm{pH}$ & -0.86 & 0.35 & -0.11 & 0.29 & -0.02 & -0.06 & 0.02 & -0.05 \\
\hline Temp & -0.17 & 0.58 & 0.03 & 0.32 & 0.22 & 0.13 & -0.34 & -0.28 \\
\hline $\mathrm{EC}$ & 0.80 & 0.24 & 0.20 & 0.21 & 0.23 & -0.28 & 0.06 & -0.04 \\
\hline TSS & 0.50 & 0.65 & -0.32 & -0.17 & -0.15 & 0.07 & 0.12 & 0.00 \\
\hline DO & -0.82 & 0.17 & -0.13 & 0.35 & 0.17 & 0.17 & -0.07 & -0.06 \\
\hline BOD & -0.73 & 0.34 & 0.14 & 0.18 & 0.15 & 0.16 & 0.27 & -0.16 \\
\hline $\mathrm{Cl}^{-}$ & -0.17 & 0.50 & 0.05 & -0.23 & -0.28 & -0.28 & 0.08 & 0.19 \\
\hline $\mathrm{SO}_{4}^{2-}$ & 0.12 & -0.01 & -0.09 & 0.39 & 0.36 & 0.01 & -0.62 & 0.46 \\
\hline $\mathrm{Ca}^{2+}$ & 0.74 & 0.20 & 0.33 & 0.06 & 0.45 & 0.03 & 0.05 & 0.15 \\
\hline $\mathrm{Mg}^{2+}$ & 0.31 & -0.36 & -0.37 & 0.67 & 0.04 & 0.10 & 0.15 & -0.11 \\
\hline $\mathrm{Na}^{+}$ & 0.24 & 0.75 & 0.25 & 0.38 & -0.06 & 0.01 & 0.11 & -0.20 \\
\hline $\mathrm{K}^{+}$ & 0.80 & 0.09 & 0.45 & 0.03 & 0.26 & 0.03 & 0.21 & -0.02 \\
\hline $\mathrm{NO}_{3}^{-}$ & -0.20 & -0.68 & 0.23 & 0.06 & -0.13 & -0.27 & -0.21 & -0.32 \\
\hline $\mathrm{NH}_{3}$ & 0.38 & 0.17 & -0.01 & -0.27 & -0.39 & 0.55 & -0.37 & -0.05 \\
\hline $\mathrm{TKN}$ & 0.28 & -0.14 & -0.57 & 0.12 & 0.08 & 0.42 & 0.36 & -0.09 \\
\hline $\mathrm{PO}_{4}^{3-}$ & 0.18 & -0.56 & 0.40 & -0.14 & 0.23 & 0.42 & -0.02 & -0.30 \\
\hline $\mathrm{Cu}$ & 0.43 & -0.29 & -0.69 & 0.02 & 0.11 & 0.05 & -0.01 & 0.13 \\
\hline $\mathrm{Fe}$ & 0.08 & -0.56 & 0.29 & 0.56 & -0.39 & -0.15 & 0.10 & 0.05 \\
\hline $\mathrm{Ni}$ & -0.58 & -0.23 & -0.03 & -0.15 & 0.46 & -0.05 & 0.31 & 0.35 \\
\hline $\mathrm{Pb}$ & -0.58 & -0.08 & 0.46 & -0.15 & 0.16 & 0.43 & 0.06 & 0.23 \\
\hline $\mathrm{Zn}$ & 0.12 & 0.03 & 0.32 & 0.41 & -0.56 & 0.31 & 0.15 & 0.46 \\
\hline Eigen values & 5.40 & 3.37 & 2.14 & 1.85 & 1.60 & 1.28 & 1.12 & 1.04 \\
\hline $\mathrm{CV} \%$ & 25.73 & 41.77 & 51.93 & 60.76 & 68.36 & 74.45 & 79.79 & 84.74 \\
\hline
\end{tabular}

Vaues in bold represent $p<0.05$

\section{Statistical analysis}

The statistical analysis of the obtained data was performed to determine significantly correlated parameters which affect the different biochemical processes in a wetland. The correlation coefficients of selected parameters were determined using the data of all 20 locations. Significant positive correlation was observed for $\mathrm{DO}$ and $\mathrm{BOD}, \mathrm{Ca}$ and $\mathrm{K}, \mathrm{Mg}, \mathrm{Cu}$, and $\mathrm{Fe}, \mathrm{PO}_{4}{ }^{3-}$ with $\mathrm{NO}_{3}{ }^{-}$, and $\mathrm{Pb}, \mathrm{NO}_{3}{ }^{-}$and $\mathrm{Fe}$. PCA was carried out to compare the compositional pattern between the physicochemical parameters along with heavy metal concentration of water samples from various sites of the wetland and to identify the factors influencing each one. PCA for the total data set is shown in Table 3, which explained eight components with eigen values $>1$ having about $84.74 \%$ of total variance in the water quality. The first component accounting for $25.73 \%$ of the total variance and was correlated (loading $\geq 0.50$ ) with $\mathrm{EC}, \mathrm{TSS}, \mathrm{Ca}^{2+}$ and $\mathrm{K}^{+}$. Cluster analysis is applied to the water quality parameters (both physiochemical and heavy metal concentration) of various sites of the lake. A dendrogram was obtained where all the 20 sampling sites of the lake were grouped into three statistically significant clusters. Cluster 1 comprises of $\mathrm{S} 1$ to $\mathrm{S} 9$ and S12 to S20; cluster 2 comprises of only S10; and lastly cluster 3 comprises of S11, respectively (Fig. 2).

\section{Conclusion}

The physicochemical characterisation revealed that the water quality of Bhindawas was compromised w.r.t. the levels of heavy metals. The general parameters (cations and anions) had minimum spatial variations and were within the safe limits level for aquatic life. The growth of submerged vegetation facilitated improved water quality, adding photosynthetically produced oxygen to water and filtering the suspended impurities. But, the addition of wastewater from adjoining villages and runoff from nearby fields has resulted in increased concentration of phosphates and heavy metals. Since these chemical species cause eutrophication and impart toxicity, respectively, the health of ecosystem and aquatic life is affected adversely. The results of this study are even more important when migratory birds use this wetland as a temporary refuge during winters. The present quality of water is unsuitable for aquatic life based on various indices of heavy metal pollution (HPI, HEI, $C_{\mathrm{d}}$ ). The wetland 
Fig. 2 Dendrogram for cluster analysis of sampling locations in Bhindawas wetland

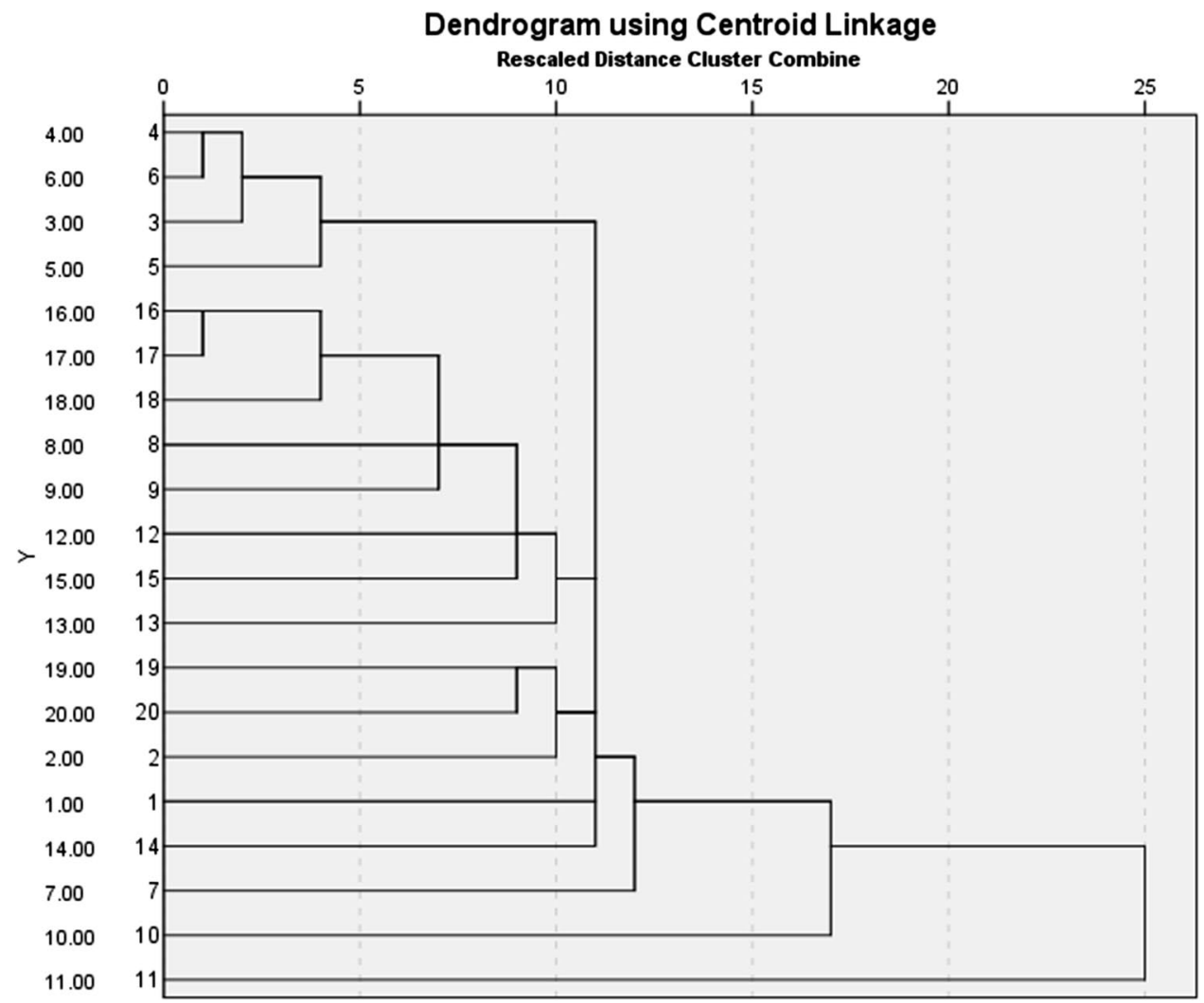

requires regular monitoring of water quality; and treatment of wastewater before being pumped into it during monsoon.

Acknowledgements The authors acknowledge help of the Chief Wildlife Warden, Haryana for the permission and help during collection of samples.

Funding The authors received no specific funding for this work.

\section{Compliance with ethical standards}

Compliance with ethics requirements manuscript includes no issue related to ethical compliance.

Open Access This article is licensed under a Creative Commons Attribution 4.0 International License, which permits use, sharing, adaptation, distribution and reproduction in any medium or format, as long as you give appropriate credit to the original author(s) and the source, provide a link to the Creative Commons licence, and indicate if changes were made. The images or other third party material in this article are included in the article's Creative Commons licence, unless indicated otherwise in a credit line to the material. If material is not included in the article's Creative Commons licence and your intended use is not permitted by statutory regulation or exceeds the permitted use, you will need to obtain permission directly from the copyright holder. To view a copy of this licence, visit http://creativecommons.org/licenses/by/4.0/.

\section{References}

Al-Mohammed FM, Mutasher AA (2013) Application of water quality index for evaluation of groundwater quality for drinking purpose in Dibdiba Aquifer, Kerbala City, Iraq. J Babylon Univ Eng Sci 21(5): $1647-1660$

APHA: Standard Methods for the Examination of Water and Wastewater (2005) 21st edn. APHA, AWWA, WPCF Washington DC, USA

Backman B, Bodis D, Lahermo P, Rapant S, Tarvainen T (1997) Application of a groundwater contamination index in Finland and Slovakia. Environ Geol 36:55-64

Bakan G, Ozkoc HB, Tulek S, Cuce H (2010) Integrated environmental quality assessment of Kizılırmak River and its coastal environment. Turk J Fish Aquat Sci 10:453-462

Brown RM, McCleiland NJ, Deininger RA, O'Connor MF (1972) A water quality index — crossing the psychological barrier. In: Jenkis SH (ed) Proceedings in international conference on water pollution research, Jerusalem, vol 6, pp 787-797

CCME (Canadian Council of Ministers of the Environment) (2007) For the protection of aquatic life 2007. In: Canadian environmental quality guidelines, 1999, Canadian Council of Ministers of the Environment, 1999, Winnipeg

Edet AE, Offiong OE (2002) Evaluation of water quality pollution indices for heavy metal contamination monitoring. A case study from Akpabuyo-Odukpani area, Lower Cross River Basin (southeastern Nigeria). GeoJournal 57:295-304

Fisher J, Acreman MC (2004) Wetland nutrient removal: a review of the evidence. Hydrol Earth Syst Sci 8(4):673-685

Giri S, Singh AK (2014) Assessment of surface water quality using heavy metal pollution index in Subaranarekha River, India. Water Qual Expo Health 5:173-182 
Gupta RC, Parasher M, Kaushik TK (2011) An enquiry into the avian biodiversity of Bhindawas Bird Sanctuary in Jhajjar District in Haryana State in India. J Exp Zool 14(2):457-465

Haritash AK, Sharma A, Bahel K (2015) The potential of Canna lily for wastewater treatment under Indian conditions. Int J Phytoremediation 17(103):999-1004

Haritash AK, Dutta S, Sharma A (2017) Phosphate uptake and translocation in a tropical Canna based constructed wetland. Ecol Process 6(12):1-7

Kaur S, Singh I (2012) Accelerated phosphate and nitrate level: factors to blame for Eutrophication in Yamuna River, Delhi, India. Int J Plant Anim Environ Sci 2:183-187

Kumar S, Dhankhar R (2012) Trophic State Index and assessment of water quality for domestic and agriculture purpose of Bhindawas wetland, Jhajjhar, Haryana (India). Ann Biol 28:144-151

Liang J, Liu J, Yuan X, Zeng G, Yuan Y, Wu H, Li F (2016) A method for heavy metal risk exposure risk assessment to migratory herbivorous birds and identification of priority pollutants/areas in wetlands. Environ Sci Pollut Res 23:11806-11813

Mohan SV, Nithila P, Reddy SJ (1996) Estimation of heavy metal in drinking water and development of heavy metal pollution index. J Environ Sci Health A31:283-289

Mohanty A, Ray S, Yadav AK, Chaudhury GR (2014) Optimization study: biological removal of inorganic nitrogen along with chemical oxygen demand from wastewater using response surface methodology. J Clean Soil Air Water 42(11):1583-1592

Prasanna MV, Praveena SM, Chidambaram S, Nagarajan R, Elayaraja A (2012) Evaluation of water quality pollution indices for heavy metal contamination monitoring: a case study from Curtin Lake, Miri City, East Malaysia. Environ Earth Sci 67:1987-2001
Rogers FEJ (1983) Wetlands as accreting systems: waste water treatment. J Limnol Soc South Afr 9(2):110-116

Saluja R, Garg JK (2014) Surface water quality assessment of Bhindawas Lake (Haryana, India) using multivariate statistical techniques. J Glob Ecol Environ 2:2454-2644

Senthil SL, Ajith Kumar TT, MarudhuPandi T, Dhaneesh KV, Murugan JB, BalaSubramanian T (2012) Metal contagion in ecologically important estuary located in Bay of Bengal. Water Qual Expo Health 4(3):137-142

Sharma M, Kansal A, Jain S, Sharma P (2015) Application of multivariate statistical techniques in determining the spatial temporal water quality variation of Ganga and Yamuna rivers present in Uttarakhand State, India. Water Qual Expo Health 7:567-581

Shelef O, Golan-Goldhirsh A, Gendler T, Rachmilevitch S (2011) Physiological parameters of plants as indicators of water quality in a constructed wetland. Environ Sci Pollut Res 18:1234-1242

Tanner CC, Clayten JS, Upsdell MP (1995) Effect of loading rate and planting on treatment of dairy farm wastewaters in constructed wetlands- - I. Removal of oxygen demand, suspended solids and faecal coliforms. Water Res 29(1):17-26

Zhang W, Liu X, Cheng H, Zeng EY, Hu Y (2012) Heavy metal pollution in sediments of a typical mariculture zone in South China. Mar Pollut Bull 64(4):712-720

Publisher's note Springer Nature remains neutral with regard to jurisdictional claims in published maps and institutional affiliations. 